\title{
EFFECT OF METABOLIC ENZYMES ON ACCELERATION ABILITY IN EXERCISE FATIGUE
}

EFEITO DAS ENZIMAS METABÓLICAS NA CAPACIDADE DE ACELERAÇÃO NA FADIGA POR EXERCÍCIO

EFECTO DE LAS ENZIMAS METABÓLICAS SOBRE LA CAPACIDAD DE ACELERACIÓN EN LA FATIGA

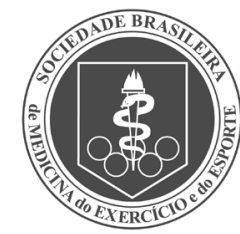

Original Article ARTIGo ORIGINAL Artículo Original

POREJERCICIO

\section{Yang Lu' (ID \\ (Physical Education Professional) Xiaoli Wang ${ }^{2}$ (DD \\ (Physical Education Professional) \\ 1. International Football Education school, Jilin Agricultural University, Changchun, China. \\ 2. Changchun Medical College, \\ Changchun, China.}

\section{Correspondence:}

Xiaoli Wang

Changchun Medical College, Changchun 130031, Jilin, China. xiaoliwangcc@126.com

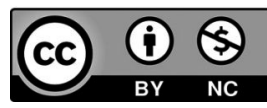

\begin{abstract}
Introduction: Study the relationship between the metabolic enzyme and the biological image, filtered by an adaptive filtering algorithm. Objective: The research aims to In this study, human metabolic enzymes were evaluated by electrocardiogram and electromyogram images, and an adaptive filtering algorithm removed the noises in the images. Methods: The electrocardiogram and electromyogram images at different periods were obtained, and the calculation method and application scope of the adaptive filtering algorithm were analysed. Results: Adaptive filter was designed by the combination of adaptive filtering algorithm and dynamic information. Therefore, the artefact of the image was removed. Conclusions: The adaptive filtering algorithm can effectively remove the noise or artefact in electrocardiogram and electromyogram signals. The optimal image information can be obtained. Level of evidence Il; Therapeutic studies - investigation of treatment results.
\end{abstract}

Keywords: Electromyogram; Electrocardiography; Enzyme; Fatigue.

\section{RESUMO}

Introdução: Estudar a relação entre a enzima metabólica e a imagem biológica filtrada por um algoritmo de filtragem adaptativa. Objetivo: O objetivo da pesquisa, neste estudo, éavaliar enzimas metabólicas humanas por meio de imagens de eletrocardiograma e eletromiograma, sendo que um algoritmo de filtragem adaptativa eliminou 0 ruído nas imagens. Métodos: Imagens de eletrocardiograma e eletromiograma foram obtidas em diferentes períodos e foram analisados o método de cálculo e o escopo de aplicação do algoritmo de filtragem adaptativa. Resultados: a filtragem adaptativa foi projetada combinando um algoritmo de filtragem adaptativa e informações dinâmicas. Portanto, o artefato foi removido da imagem. Conclusões: $O$ algoritmo de filtragem adaptativa pode efetivamente eliminar ruído ou artefato em sinais de eletrocardiograma e eletromiograma. Informações de imagem ideais podem ser obtidas. Nível de evidência ll; Estudos terapêuticos: investigação dos resultados do tratamento.

Descritores: Eletromiograma; Eletrocardiografia; Enzima; Fadiga.

\section{RESUMEN}

Introducción: Estudiar la relación entre la enzima metabólica y la imagen biológica, filtrada por un algoritmo de filtrado adaptativo. Objetivo: La investigación tiene como objetivo, en este estudio, evaluar las enzimas metabólicas humanas mediante imágenes de electrocardiograma y electromiograma, y un algoritmo de filtrado adaptativo eliminó los ruidos en las imágenes. Métodos: Se obtuvieron las imágenes de electrocardiograma y electromiograma en diferentes períodos y se analizó el método de cálculo y alcance de aplicación del algoritmo de filtrado adaptativo. Resultados: El filtrado adaptativo se diseñó mediante la combinación de un algoritmo de filtrado adaptativo e información dinámica. Por lo tanto, se eliminó el artefacto de la imagen. Conclusiones: El algoritmo de filtrado adaptativo puede eliminar eficazmente el ruido o artefacto en las señales de electrocardiograma y electromiograma. Se puede obtener la información de imagen óptima. Nivel de evidencia ll; Estudios terapéuticos: investigación de los resultados del tratamiento.

Descriptores: Electromiograma; Electrocardiografía; Enzima; Fatiga.

\section{INTRODUCTION}

Sports fatigue is not harmful to health, and the accelerated recovery can be obtained by a certain level of fatigue during physical exercise. And results from some studies showed that with the difference of the active state in human body, the metabolic enzyme activity in human body changed. At present, the activity of enzyme is detected by the blood test, which seriously affects the application of enzyme activity index in the evaluation of human body state. ${ }^{1}$
The electrocardiogram (ECG or EKG) is a technique. The image of electrical activity is recorded by it from the body surface. Electromyogram (EMG) is the muscle bioelectrical image recorded by myoelectric apparatus, which has great significance for the evaluation of human activities in man-machine system. ${ }^{3}$ The adaptive filtering theory was proposed by Zhao et al. in the 1960s, ${ }^{6}$ which was the best filtering method developed on the basis of linear filtering such as wiener filtering and kalman filtering. The weight coefficient of the adaptive filter system was adjusted 
automatically through little or no prior knowledge of the input signal and noise, and the optimal state was achieved. Therefore, this filter had the characteristics of non-stationary and nonlinear, and had a good effect on the removal of noise generated by human dynamics in ECG and EMG images.It has no effect on the baseline drift, and EMG interference and power frequency interference in the frequency domain..$^{5}$ The adaptive filtering theory was proposed by Zhao et al. in the 1960s, ${ }^{6}$ which was the best filtering method developed on the basis of linear filtering such as wiener filtering and kalman filtering. The weight coefficient of the adaptive filter system was adjusted automatically through little or no prior knowledge of the input signal and noise, and the optimal state was achieved. Therefore, this filter had the characteristics of non-stationary and nonlinear, and had a good effect on the removal of noise generated by human dynamics in ECG and EMG images.

In conclusion, the physical status of a person was assessed by ECG and EMG. Through the combination of metabolic enzyme index and corresponding ECG and EMG image, the fatigue recovery rate and degree of personnel were evaluated by biological image. In this study, the changes of metabolic enzyme activity in exercise fatigue were combined with the changes of ECG and EMG images. Meanwhile, the signal noises were removed and the optimal results were obtained by adaptive filtering algorithm. Therefore, the experimental guidance was provided for the noise processing of related biological images.

\section{METHODS}

\section{Experiment for information acquisition of ECG, EMG and metabolic enzymes}

Sixty volunteers with an average age of $33.12 \pm 4.56$ years were recruited as experimental subject, and there were 18 females and 42 males. Excessive activities were avoided for 24 hours before the start of the experiment, and the muscles of all the experimenters were relaxed by regular warm-up activities after the start of the experiment. The electrocardiogram electrode slice was attached to the corresponding position in the chest of the experimenter, and the electromyographic electrode slice was attached to the vastus lateralis muscle. After football training for one hour, 49 cases of sports fatigue were selected according to the subjective fatigue consciousness scale of the volunteers. The enzyme activity in the serum was detected by a blood test. After a 30-minute rest, the blood samples of 49 volunteers were collected, and ECG and EMG were performed on them, the enzyme activity was also tested. The enzyme activity data were compared with the corresponding ECG and EMG.

Inclusion criteria: volunteer for this study; healthy adults; people with good physical ability. exclusion criteria: people with severe cardiopulmonary disease and unfit for strenuous activities; people with other mental or trunk diseases; pregnant or nursing women; people with other serious systemic diseases.

\section{Noise removal model under the adaptive filtering algorithm}

Figure 1 was the structure diagram of the adaptive filter. If the order of adaptive filtering was $M$, the filter coefficient was $W$, and the input signal sequence was $X$, the output was as follows:

$$
\mathrm{y}(\mathrm{n})=\sum_{\mathrm{m}=0}^{M-1} W(m) X(\mathrm{n}-\mathrm{m})
$$

$$
e(n)=d(n)-y(n)
$$

In this equation, $d(n)$ was the expected signal, e(n) was the error signal, $n$ was the total signal, and $m$ was the specific time sequence signal:

$$
W=\left[W_{0}, W_{1}, L, W_{M-1}\right]^{T}, \mathrm{X}_{\mathrm{j}}=\left[X_{1 j}, \mathrm{X}_{2 j}, L, X_{N j}\right]^{T}
$$

The output of the filter was written as a matrix, as follows:

$$
y_{j}=X_{j}^{T} W=W^{T} X_{j}
$$

$$
e_{j}=d_{j}-y_{j}=d_{j}-X_{j}^{T} W=d_{j}-W^{T} X_{j}
$$

The definition cost function of adaptive filtering was as follows:

$$
J(j)=E\left[e_{j}^{2}\right]=E\left[\left(d_{j}-W^{T} X_{j}\right)^{2}\right]
$$

The optimal filtering was realized, when the minimum value was taken by the cost function above. The adaptive filtering was called least mean square adaptive filtering (LMS). The Minimum mean square error was obtained by the filter coefficient, and the filter coefficient was determined by gradient descent. The iterative formula of the filter coefficient vector was as follows:

$$
W_{j+1}=W_{j}+\frac{1}{2} \mu\left(-\nabla J_{j}\right)
$$

In this equation, $\mu$ was the step size factor, $\nabla J_{j}$ was the step size factor. The instantaneous gradient -2Xjej was an unbiased estimate of the true gradient. The real gradient was replaced by instantaneous gradient in practical application. The equation was as follows:

$$
\nabla J_{j}=-2 X_{j}\left(d_{j}-W^{T} X_{j}\right)=-2 X_{j} \ell_{j}
$$

$$
W_{j+1}=W_{j}+\mu X_{j} \ell_{j}
$$

The real gradient was replaced by instantaneous gradient in practical application. The equation was as Figure 1.

\section{RESULTS}

\section{ECG image processing results and signal analysis}

The obtained ECG images were denoised by the minimum mean square adaptive filtering of adaptive filtering algorithm, and the results

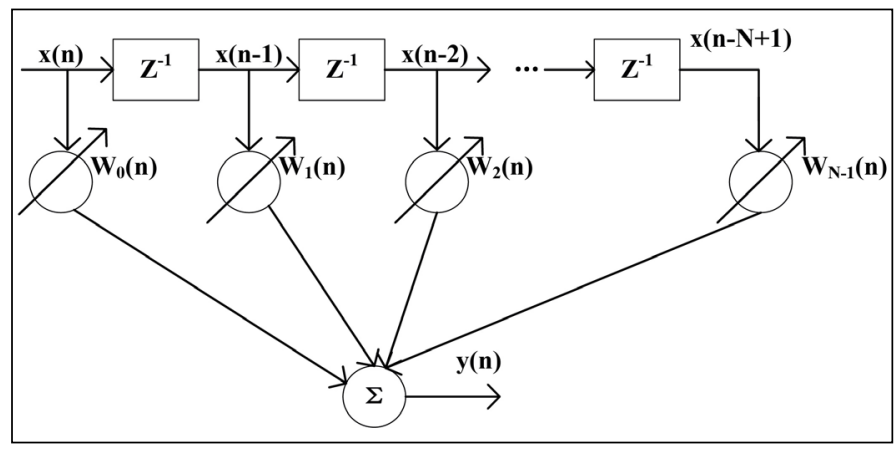

Figure 1. Adaptive filter structure diagram. 
were shown in Figure 2. A was the ECG sequence diagram of the experimenter in the activity state, and B was the ECG sequence diagram after denoising by the adaptive filtering algorithm. From the figure, the ECG waveform dithering collected under the condition of exercise was serious, and the amplitude of the disturbance was greater than the $\mathrm{R}$ crest. Therefore, the distinction of the $\mathrm{R}$ crest was difficult, and the data we need was not obtained.

In this study, 49 experimenters in the period of exercise fatigue were selected by the subjective fatigue consciousness scale (RPE). Their ECG images were collected again and compared after a 30-minute rest. The comparison results were shown in Figure 3, A was the ECG of the experimenter during fatigue period, and B was the ECG of the experimenter after a 30-minute rest. The RP gap narrowed and the ECG amplitude significantly decreased, when the experimenter was in the fatigue phase. However, the ECG became regular and smooth when the experimenter rested for 30 minutes. The results showed that the state of the person's body, and the speed and degree of fatigue recovery were reflected by ECG.

\section{Signal analysis and processing results of EMG image}

Figure 4 was EMG of rectus femoris before and after treatment. The figure showed that the dynamic muscle operation of the experimenter had a serious impact on the EMG image. Meanwhile, the interference had serious randomness and large amplitude, no information from the original EMG image were obtained. The baseline drift and dynamic interference of the processed EMG images were removed, and the waveform of the electromyographic signal was clearly visible.

The EMG of 49 experimenters during fatigue and after a 30-minute rest were compared, and the results were shown in Figure 5. A was the EMG of the experimenter during fatigue period, and B was the EMG of the experimenter after a 30-minute rest. The amplitude of EMG increased significantly and the waveform decreased, when the experimenter was in the fatigue phase. However, the EMG of experimenters showed strong regularity after a 30-minute rest. The results showed that the speed and degree of fatigue recovery, and the state of the person's body were reflected by EMG.

\section{Comparative analysis of metabolic enzymes and ECG and EMG}

Blood samples were taken from 49 experimenters, and the activity of glutathione peroxidase (GSH-PX), serum creatine kinase (CK) and superoxide dismutase (SOD) in the serum were detected and analysed. The activity of relevant metabolic enzymes during fatigue and after rest was compared, and the results were shown in table 1. After a 30-minute rest, the GSH-PX activity and SOD content in the laboratory increased significantly, but the $C K$ content decreased significantly $(P<0.05)$. The ECG and EMG characteristics of the experimenters in different metabolic enzyme states were significantly different.
A

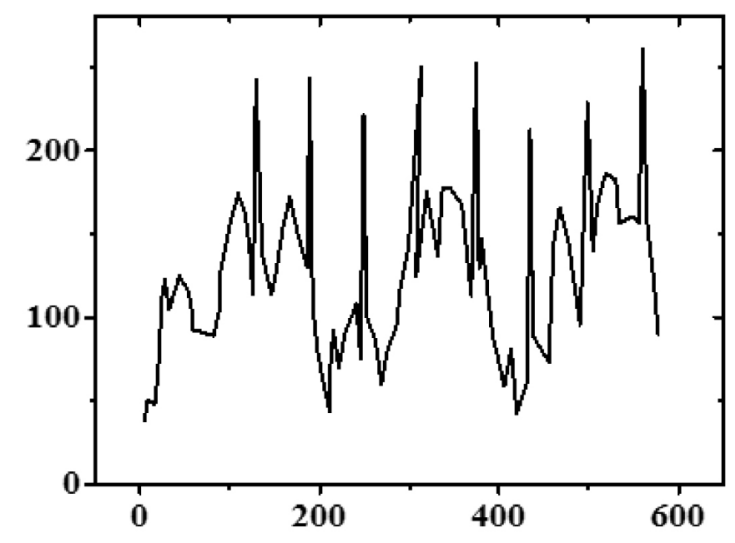

B

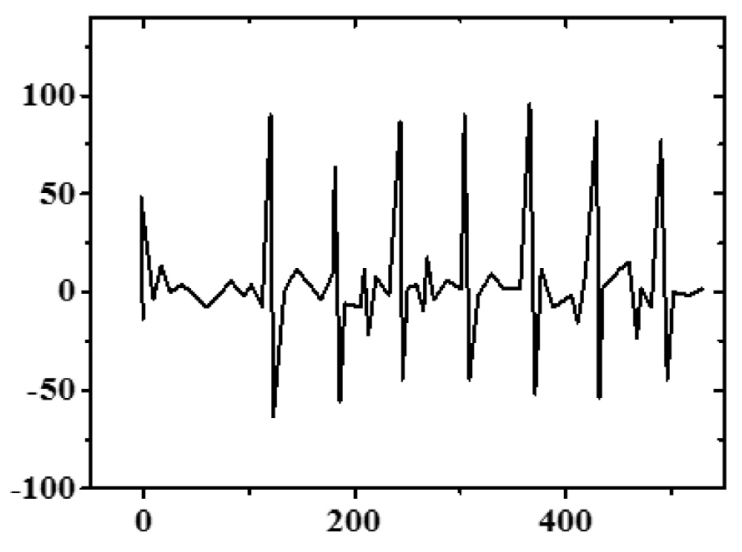

Note: A was the ECG sequence diagram of the experimenter in the activity state, and B was the ECG sequence diagram after denoising by the adaptive filtering algorithm

Figure 2. Comparison of ECG denoising before and after.

A

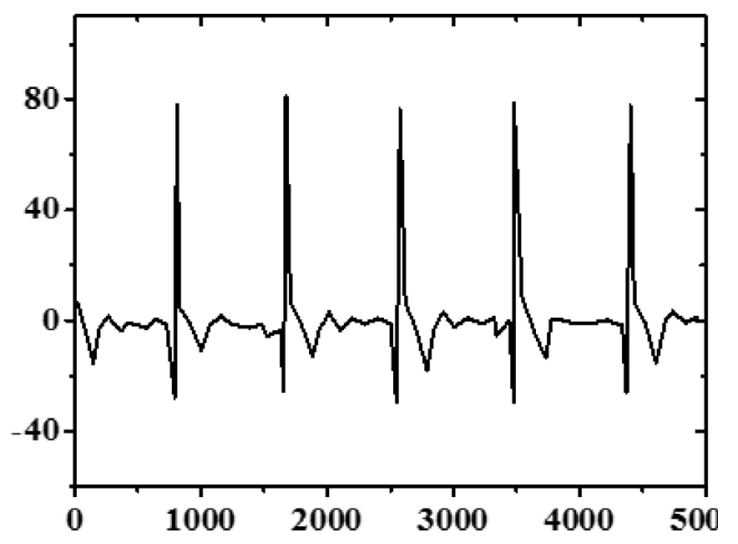

B

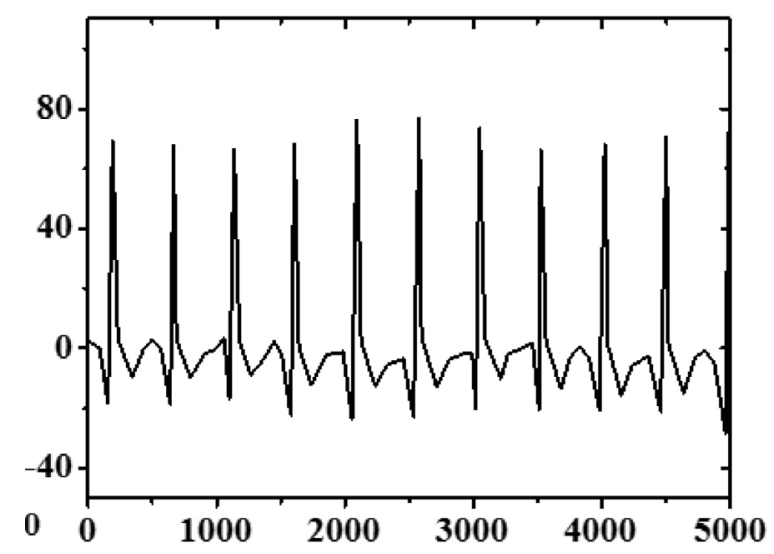

Note: A was the ECG of the experimenter during the fatigue period, and B was the ECG of the experimenter after a 30-minute rest.

Figure 3. Comparison of the ECG of experimenters at different periods. 


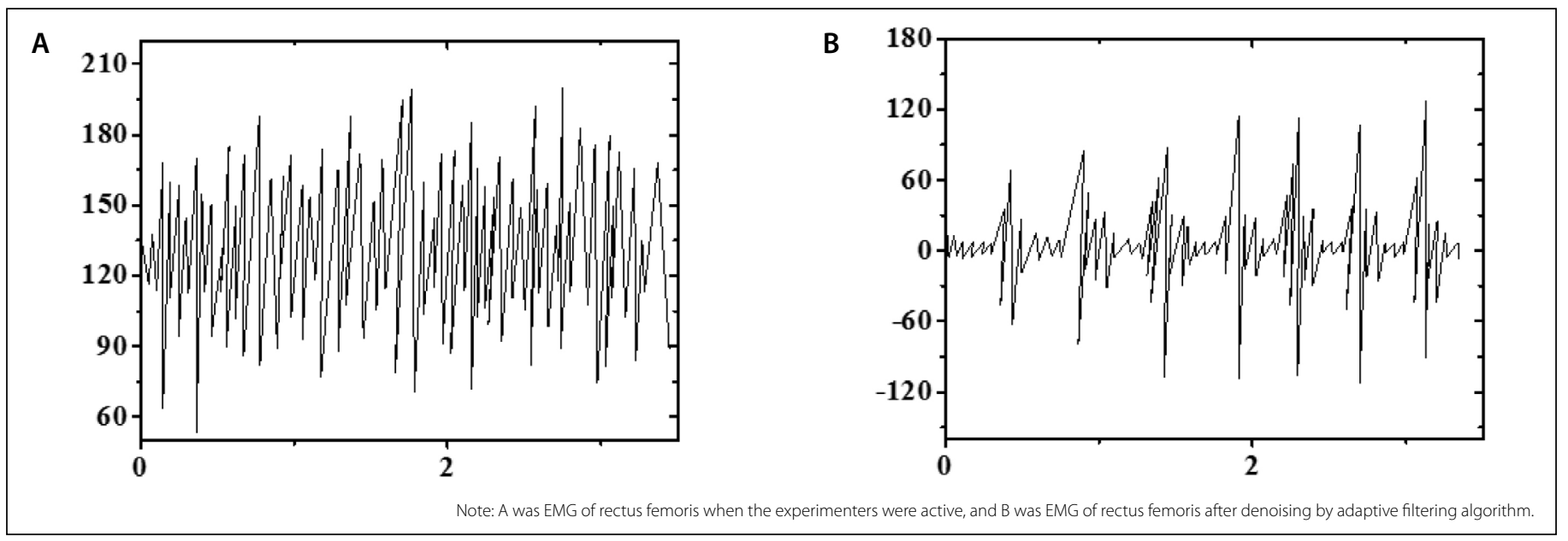

Figure 4. EMG of rectus femoris before and after treatment.

\section{A}

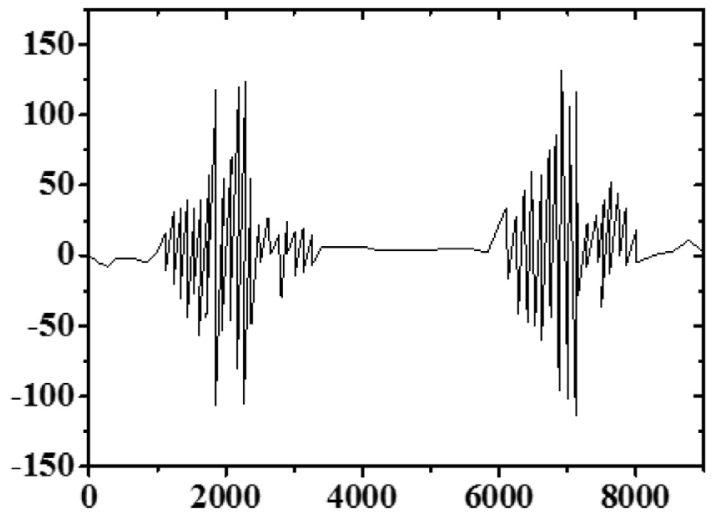

B

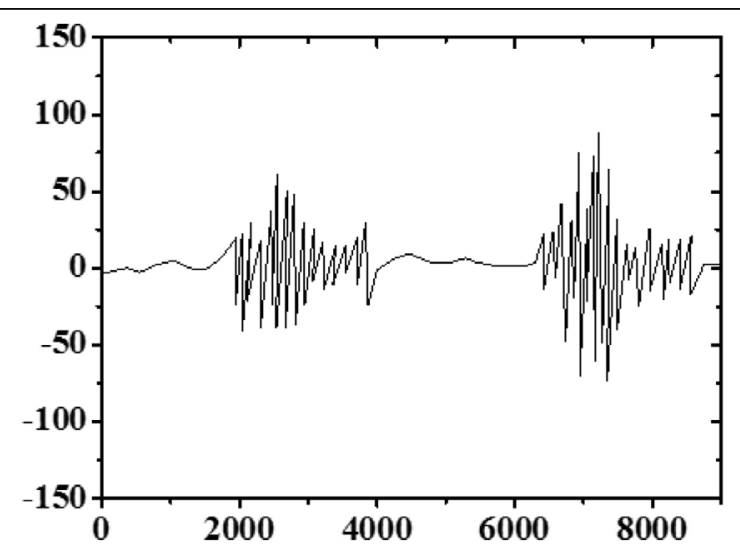

Note: A was the EMG of the experimenter during fatigue period, and B was the EMG of the experimenter after a 30-minute rest.

Figure 5. Comparison of EMG of experimenters at different periods.

Table 1. Serum enzyme-related metabolic enzyme contents of the experimenters in different periods.

\begin{tabular}{c|c|c|c|c|c}
\hline & GSH-PX & SOD (NU/ml) & CK (U/L) & ECG character & EMG character \\
\hline $\begin{array}{c}\text { Fatigue } \\
\text { period }\end{array}$ & 170.45 & 171.32 & 322.89 & $\begin{array}{c}\text { RP gap } \\
\text { narrowed and } \\
\text { ECG amplitude } \\
\text { decreased }\end{array}$ & $\begin{array}{c}\text { The amplitude } \\
\text { increased and } \\
\text { the waveform } \\
\text { decreased }\end{array}$ \\
\hline $\begin{array}{c}\text { After a } \\
\text { 30-minute } \\
\text { rest }\end{array}$ & $185.34^{*}$ & $190.64^{*}$ & $303.45^{*}$ & $\begin{array}{c}\text { Regular and } \\
\text { smooth }\end{array}$ & strong regularity \\
\hline
\end{tabular}

Note: The ${ }^{*}$ in the table indicated a significant difference compared with the fatigue period, $P<0.05$.

\section{DISCUSSION}

At present, ECG and EMG are widely used in human body detection and have developed into a very mature biological image technology. In this research, the noise of graphics was reduced by adaptive filtering algorithm. The adaptive filter was a wiener filter, and the optimization of it was achieved by the adjustment of transmission characteristics. No prior knowledge of the input information was required, the filter was particularly suitable for real-time processing. ${ }^{10}$ The results of this research showed that the weights and parameters were optimized by the adaptive filter according to the dynamic information. The suppression of the external interference and the automatic match of adaptive filter with the noise were achieved, therefore, the easily recognizable ECG and EMG images were obtained.

\section{CONCLUSIONS}

The heartbeat and muscles of the experimenter were in a state of continuous deepening and activation, and the obtained artefact noise was more random. Therefore, the spectrum was overlapped with electrocardiogram and electromyogram signals, and no real and effective data was obtained. Adaptive filter was designed by the combination of adaptive filtering algorithm and dynamic information. Therefore, the artefact of the image was removed. Meanwhile, the weights and related parameters of adaptive filter were optimized by the dynamic information, and the automatic match of adaptive filter and noise was achieved, and the external interference was also suppressed. When the experimenter was in the fatigue phase, the RP gap narrowed and the ECG amplitude significantly decreased. The EMG amplitude significantly increased and the waveform decreased. After a 30-minute rest, the ECG became regular and smooth, and the EMG showed strong regularity. There were significant differences in the content of related metabolic enzymes before and after rest $(P<0.05)$. In conclusion, the noise interference of ECG and EMG were eliminated by adaptive filtering algorithm, and the ECG and EMG data were achieved reliably and clearly. Therefore, the adaptive filtering algorithm can be applied to the actual image noise reduction. This also provides experimental basis for other related image processing.

All authors declare no potential conflict of interest related to this article 


\section{REFERENCES}

1. Alvarez-Gonzalez LC, Briceño A, Ponce-Garcia G, Villanueva-Segura OK, Davila-Barboza JA, Lopez-Monroy B, et al. Assessing the effect of selection with deltamethrin on biological parameters and detoxifying enzymes in Aedes aegypti (L.). Pest Manag Sci. 2017;73(11):2287-93.

2. Takahashi M, Ogawa T, Kashiwagi H, Fukushima F, Yoshitsugu M, Haba M, et al. Chemical synthesis of an indomethacin ester prodrug and its metabolic activation by human carboxylesterase 1. Bioorg Med Chem Lett. 2018;28(6):997-1000.

3. Karikalan $\mathrm{G}$, Rajangam U. Effect of Marsilea quadrifolia on carbohydrate metabolic enzymes in alloxan induced diabetic rats. J Pharm Investig. 2017 [cited 2021 Jun 14];48(1):1-10. Available from: https:// www.semanticscholar.org/paper/Effect-of-Marsilea-quadrifolia-(L.)-on-carbohydrate-Karikalan-Ra jangam/98dc58052d18b5f2d4dd7a681afc6ce2c25d24ac

4. Johnston B. "An eye for an eye leaves the whole world blind"-Mahatma Gandhi. Annals of Applied Biology. 2019;144(3):273-83.

5. Kauppi K, Korhonen V, Ferdinando H, Kallio M, Myllyla T. Combined surface electromyography, near-infrared spectroscopy and acceleration recordings of muscle contraction: The effect of motion. Journal of Innovative Optical Health Sciences. 2017 [cited 2021 Jun 14];10(2):13. Available from: http://www.opticsjournal.net/M/Articles/Abstract/jiohs/10/2/1650056.cshtml
6. Zhao PY, Huang XP. An improved spectral analysis method for fatigue damage assessment of details in liquid cargo tanks. China Ocean Engineering. 2018 [cited 2021 Jun 14];32(1):62-73. Available from https://www.x-mol.com/paper/1335609183458259055?adv

7. Foster SR, Dilworth LL, Thompson RK, Alexander-Lindo RL, Omoruyi FO. Effects of combined inositol hexakisphosphate and inositol supplement on antioxidant activity and metabolic enzymes in the liver of streptozotocin-induced type 2 diabetic rats. Chem Biol Interact. 2017;275:108-115.

8. Duan $X$, Yang $Y$, Wang S, Feng $X$, Wang T, Wang $P$, et al. Cross-sectional associations between genetic polymorphisms in metabolic enzymes and longer leukocyte telomere length induced by omethoate. Oncotarget. 2017;8(46):80638-44.

9. Yao F, Chen L, Fan Z, Teng F, Zhao Y, Guan F, et al. Interplay between H6PDH and 11 $\beta$-HSD1 implicated in the pathogenesis of type 2 diabetes mellitus. Bioorg Med Chem Lett. 2017;27(17):4107-13.

10. Chukwuma Cl, Mopuri R, Nagiah S, Chuturgoon AA, Islam MS. Erythritol reduces small in testinal glucose absorption, increases muscle glucose uptake, improves glucose metabolic enzymes activities and increases expression of Glut- 4 and IRS- 1 in type 2 diabetic rats. Eur J Nutr. 2018;57(7):2431-44 